\title{
513
}

\section{the iolva}

revielv

\section{SUMMER 1974}

\section{POETRY}

Ernest Sandeen Joyce Peseroff

Ross Talarico

Mick Fedullo

Thomas Lux

David Wagoner

Lawrence Raab

Russell Edson

Jack Myers

Vickie Karp

Keith Althaus

John Graber

Franco Fortini

Peter Huchel

\section{FICTION}

MacDonald Harris

Nancy Stone

Frank Stanford

Diane Vreuls

Arthur Oberg

JOURNALIT

Leo Raditsa on Paul Goodman

\section{CRITICISM}

Charlotte Gafford on Fielding Dawson, with sections of a new novel by Dawson Arthur Oberg on Robert Lowell 
Volume 5 Number 3

Contents

\begin{tabular}{|c|c|c|c|}
\hline \multirow[t]{24}{*}{ POETRY } & Ernest Sandeen & $\begin{array}{l}\text { The Poem Is Showing } \\
\text { The Poem Dresses Up Like Love } \\
\text { The Poem as a Private Persecutor } \\
\text { The Poem Out on a Night Mission }\end{array}$ & $\begin{array}{l}4 \\
4 \\
5 \\
5\end{array}$ \\
\hline & Joyce Peseroff & The Continental Drift & 7 \\
\hline & Ross Talarico & For the Moment & 8 \\
\hline & Mick Fedullo & Blue Nude & 9 \\
\hline & Thomas Lux & Every Ventricle & 10 \\
\hline & & Letter from Zanzibar & 11 \\
\hline & & This Disappearance & 12 \\
\hline & David Wagoner & Who Shall Be the Sun? & 13 \\
\hline & Lawrence Raab & The Body Tries to Give Itself Up & 15 \\
\hline & Russell Edson & The Heavenly Hunger & 16 \\
\hline & & Professor Galapogos on the Floor & 17 \\
\hline & Jack Myers & The Commonwheel & 18 \\
\hline & & Sunbathing & 19 \\
\hline & Vickie Karp & Looking for God & 20 \\
\hline & & The Still Hand & 21 \\
\hline & Keith Althaus & Inside Work & 22 \\
\hline & & The Hunter & 22 \\
\hline & John Graber & Like Land Used Up & 23 \\
\hline & Franco Fortini & The Trees & 24 \\
\hline & & In Memoriam I & 24 \\
\hline & & In Memoriam III & 25 \\
\hline & & The Present & 26 \\
\hline & Peter Huchel & Spinney ... & 27 \\
\hline & & The Angels & 28 \\
\hline \multirow[t]{5}{*}{ Fiction } & MacDonald Harris & Dr. Pettigot's Face & 30 \\
\hline & Nancy Stone & Act $V$ & 37 \\
\hline & Frank Stanford & A Past: Wintered Like a Circus & 39 \\
\hline & Diane Vreuls & The Alice P. Gamboe Strip & 55 \\
\hline & Arthur Oberg & Anna's Song & 59 \\
\hline JOURNALIT & Leo Raditsa & On Paul Goodman-And Goodmanism & 62 \\
\hline \multirow[t]{4}{*}{ CRITICISM } & Charlotte Gafford & $\begin{array}{l}\text { Fielding Dawson's “Certain Overflow } \\
\text { Willingness" }\end{array}$ & 82 \\
\hline & Fielding Dawson & Three sections from “A Capitol Ship" & 88 \\
\hline & Arthur Oberg & "Lowell" Had Been Misspelled "Lovel" & 98 \\
\hline & & $\begin{array}{l}\text { Notes on Contributors } \\
\text { Next Issue }\end{array}$ & $\begin{array}{l}123 \\
125\end{array}$ \\
\hline
\end{tabular}


The Iowa Review is a literary quarterly sponsored and published by the School of Letters and the Graduate College of The University of Iowa and printed by The University of Iowa Printing Service.

Copyright (C) 1974, by The University of Iowa.

Second class postage paid at Iowa City, Iowa 52240 .

Send subscriptions to the Department of Publications, The University of Iowa, Iowa City, Iowa 52242.

Manuscripts should be sent, with a self-addressed, stamped envelope, to The Iowa Review, EPB 453, The University of Iowa, Iowa City, Iowa 52242 .

Merle E. Brown, Editor

Thomas R. Whitaker, Acting Editor Page Edwards, Jr., Managing Editor Michael Ryan, Poetry Editor Michael Burkard, Poetry Editor David Hayman, Fiction Editor Susan Engberg, Assistant Fiction Editor David St. John, Editorial Assistant

T. Coraghessan Boyle, Editorial Assistant 

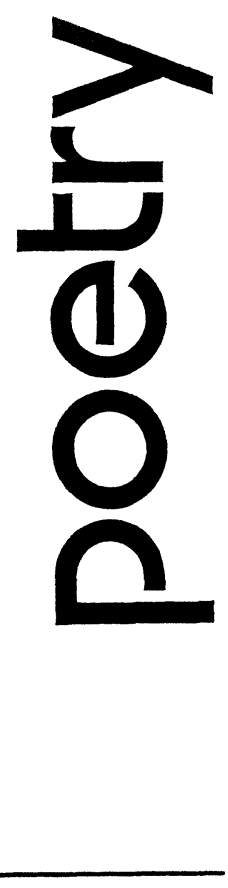


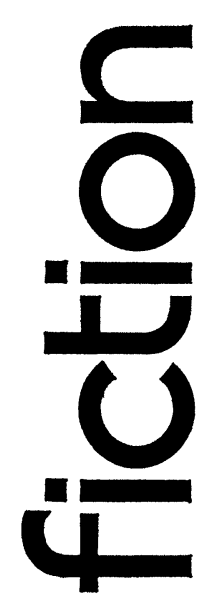

$\longrightarrow$ 

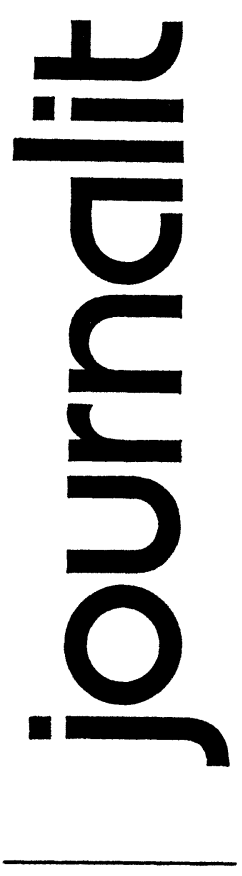


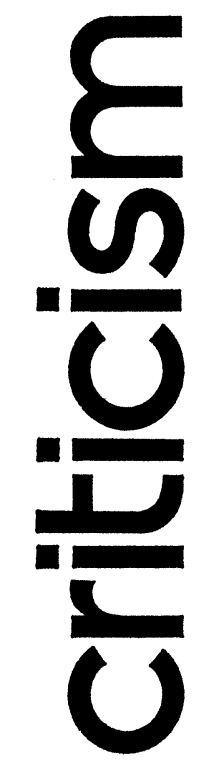

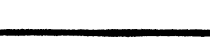

